\title{
O TRIBUNAL CONSTITUCIONAL DA COSTA RICA
}

\author{
Marvin Carvajal Pérez \\ Bacharel e Licenciado em Direito pela Universidad de Costa Rica \\ Doutorando em Direito do Estado na Universidade de São Paulo
}

Resumo:

A criação, em 1989, do Tribunal Constitucional da Costa Rica, tem significado para esse país centro-americano uma verdadeira revolução institucional, cuja dinâmica a partir daí aproximou-se da normatividade constitucional. O tribunal é formado por sete juízes especializados na matéria, e tem competência ampla para conhecer de recursos tendentes à proteção dos direitos fundamentais ("amparo" e "habeas corpus"), bem como para efetuar o controle da constitucionalidade dos atos normativos mediante as consultas judiciais e legislativas de constitucionalidade e a ação direta de inconstitucionalidade. Seu funcionamento encontra-se regido pelos princípios de celeridade, gratuidade, consideração de defesa da constituição como um assunto de interesse público, amplitude do parâmetro de constitucionalidade até abranger as normas do direito internacional devidamente ratificadas pelo legislativo, os princípios e o costume constitucionais, etc.

\begin{abstract}
:
The criate, in 1989, of Costarrican Constitutional Court, represented in that central american country a really institutional revolution, nearing it to the constitutional normativity. The court is formed by seven especializated judges, with competence to know process about protection of human rights ("amparo" and "habeas corpus"); has a incumbence to control the constitutionality of law, using the process of judicial and legislative consult and the direct action of constitutionality. Its function is directed by the principles of celerity, not expensive costs, consideration of constitutional defense like an public interested point, amplity of constitutional parameter including international norms ratificated by legislative, costumes and principles consagraded by constitution.
\end{abstract}

Unitermos: Sistema jurídico costarriquense - Tribunal Constitucional costarriquense.

* Agradecimento especial pela colaboração prestada ao autor merecem os professores Manoel Gonçalves Ferreira Filho, Sérgio Resende de Barros e Ernesto Lippmann. 
Sumário:

Introdução.

Parte I: O sistema jurídico da Costa Rica:

A a Constituição Política de 1949:

1 - a limitação do poder,

2- a distribuição do poder.

B - a estrutura do Poder Judiciário:

1 - órgãos que o compõem,

2- a Corte Suprema de Justiça.

Parte II: O Tribunal Constitucional Costarriquense:

A - princípios inspiradores de sua função;

B - competências em matéria constitucional:

1 - jurisdição da liberdade:

a. recurso de habeas corpus,

b. recurso de amparo.

2- controle de constitucionalidade:

a. consultas de constitucionalidade,

b. ação de inconstitucionalidade.

3- outras competências.

Conclusão.

Bibliografia.

Introdução

Um dos mais marcantes traços da ciência jurídica brasileira e de outros aspectos de sua cultura é o fato dela estar voltada inteiramente para o estudo de seus problemas nacionais e dos que acontecem nos países centrais, principalmente na Europa ocidental e nas nações anglo-saxônicas. Porém, a experiência jurídica dos outros países latino-americanos, caracterizados por uma evolução histórica comum e por problemas sociais, econômicos e políticos muito similares aos brasileiros, geralmente não recebe suficiente atenção. Similar fenômeno acontece nos outros países da América Latina.

Este curto trabalho tem a intenção de mostrar a experiência no campo da defesa da normatividade constitucional da Costa Rica, pequeno país da América 
Central. Em especial depois da criação, em 1989, de um Tribunal especial na matéria e que produziu uma verdadeira revolução institucional a nível interno, chegando a despertar a atenção dos estudiosos do tema no mundo inteiro, pelos particulares resultados obtidos desde que entrou em funcionamento. Não é propriamente um texto de direito comparado, pois o sistema empregado é apenas a simples descrição de uma instituição implementada em outro país, sem se aprofundar nas semelhanças ou diferenças que possam existir com relação a outros modelos.

A importação de estruturas burocráticas alheias, sem uma verdadeira base institucional que as respalde, não oferece maiores possibilidades de sucesso e não representa nenhuma vantagem importante; mas o estudo das respostas dadas por nações também periféricas a problemas similares pode pelo menos contribuir em alguma medida para a solução das dificuldades que ainda atravessam os países latino-americanos, no lento caminho que leva à consolidação de suas instituições democráticas.

Parte I: O sistema jurídico da Costa Rica ${ }^{1}$

Costa Rica é um Estado da América Central, de 51,1 mil quilômetros quadrados e cerca de três milhões de habitantes, de população composta principalmente pelos descendentes das populações autóctones, dos colonos espanhóis e uma mistura de raças vindas de diversos fluxos migratórios acontecidos ao longo da história (chineses, europeus, jamaicanos e outros latino-americanos, principalmente).

Antes de sua independência em 1821, formou parte da Capitania Geral da Guatemala, junto com outros quatro atuais Estados centro-americanos: Guatemala, Honduras, El Salvador e Nicarágua. Depois, experimentou alternadamente a soberania e a autonomia federativa, até que em 1841 se converteu em República independente, não sendo nunca mais discutida, oficialmente, a possibilidade de voltar a ser uma província ou Estado-membro de uma federação.

1. Empregaremos o termo "sistema jurídico" num sentido restrito apenas à ordem hierarquizada e coerente, existente entre as diversas instituições estabelecidas ou reconhecidas pela Lei Fundamental, com o qual resulta como sinônimo a palavra "ordem constitucional". deixando de lado considerações de caráter sociológico ou político. Ver Kelsen, Hans, Teoria General del Derecho y del Estado, Imprenta Universitária, México, 1949, Gutiérrez, Carlos José, El Funcionamiento del Sistema Jurídico, Editorial Juricentro, San José, 1979. 
No total, ao longo de toda a sua vida jurídica, Costa Rica foi dirigida por quatorze constituições, sendo a primeira a Constituição de Cádiz de 1812, a que o país se submetia em razão de ser uma província espanhola. Com a ruptura dos laços coloniais com a Espanha, o país experimentou um período de ensaio constitucional, que vai de 1821, ano em que fora emitido o Pacto Social Interino de Costa Rica, até 1871, quando entrou em vigor uma Lei Fundamental de marcante influência liberal, que vigoraria durante setenta e oito anos, com uma única exceção: a Constituição de 1917 , de curta vida. ${ }^{2}$

A Carta Política de 1871 , de ordem liberal clássica, não conseguiu manter-se imune às novas idéias trazidas pela revolução bolchevique e pela doutrina social da Igreja. Por isso, foi emendada em 1940 para a introdução dos princípios trabalhistas de jornada de oito horas, descansos periódicos, previdência social etc., bem como para a criação da Universidade de Costa Rica, que produziria posteriormente as mentes que respaldaram ideologicamente a revolução de 1948, que veio a culminar com a promulgação, em novembro de 1949, da Constituição em vigor até hoje.

\section{A a Constituição Política de 1949}

A finais da década de 1940, o país encontrava-se envolvido em uma forte instabilidade nas diversas ordens do sistema social. O velho esquema da Carta de 1871 não resistia às demandas cada vez maiores dos agentes sociais, uns pela manutenção do status quo e os outros pela mudança das condições de vida. Aliás, quadros novos de intelectuais produzidos na universidade pública e uma nascente pequena burguesia industrial já começavam a lutar por uma participação cada vez maior no poder político, até então reduto da burguesia agrária surgida no século XIX.

Nesse contexto, em 1948, foram anuladas pelo Congresso as eleições presidenciais, das quais tinha saído vitorioso o setor liberal, apoiado pelas tendências de centro-esquerda (nova elite intelectual) contra os grupos conservadores, que, seguindo o exemplo da aliança EUA-URSS na Segunda Grande Guerra, estavam aliados aos comunistas, com a bênção da Igreja católica.

2. Saenz Carbonel, Jorge Francisco, El Despertar Constitucional de Costa Rica, Libro Libre, San José, 1985, pp. 238-427. 
Aproveitando-se da conjuntura, os social-democratas iniciaram uma guerra civil que se manteria por alguns meses, para a qual tiveram o apoio financeiro de seus aliados nas eleições de 1948 e logístico da chamada "Legião do Caribe", grupo armado formado por forças de vários países, que alegavam lutar pela restauração da democracia na região.

A guerra foi perdida pelo governo e, em 1949, depois da instituição de uma junta provisória, foi convocada uma Assembléia Constituinte, tendo como resultado a elaboração da Constituição Política da República da Costa Rica, em 7 de novembro de 1949. Esta Carta reúne características tão-significativas, quão paradoxais, devido principalmente à composição da Constituinte.

Com efeito, a coalizão desses dois grupos vencedores da guerra civil formou a Assembléia Constituinte, sendo que a bancada liberal defendeu a manutenção da Carta de 1871, apenas modificando aspectos relativos ao sufrágio e sua fiscalização; por sua parte, os social-democratas levaram um novo projeto inspirado em ideais socialistas tendentes à instauração do Estado regulador e interventor.

Da delicada mistura de ambas as propostas é que surge a Lei Fundamental de 1949, cujos caracteres serão explicados nos dois itens que seguem, cada um deles dedicado ao estudo das duas partes que basicamente compõem uma constituição: a organização dos agentes públicos e a proteção do âmbito de direitos dos particulares.

1- a limitação do poder

A Carta Política de 1949 reconhece a existência de direitos pertencentes a cada habitante da República. Além de praticamente copiar o texto das principais declarações de direitos individuais, introduz o conceito dos direitos sociais, também chamados da "segunda geração" surgidos no cenário político mundial como conseqüência de dois importantes fatos: a crise financeira de 1929, que levou a adotar um sistema de comando da economia pelo do Estado; e o desgaste do capitalismo concorrencial desde o final do século XIX, somado à vitória dos bolcheviques na Revolução russa, que levou a uma proliferação das idéias de justiça social e igualdade real, que desencadearam um processo de reconhecimento de direitos de caráter social. ${ }^{3}$

3. Bobbio, Norberto, Liberalismo y Democracia, México, Fondo de Cultura Económica, 1992, p. 11. 
Assim, no campo dos direitos individuais (chamados de primeira geração), são reconhecidos expressamente os seguintes direitos: a liberdade individual, a inviolabilidade da vida, a liberdade de locomoção, a intimidade, o sigilo das comunicações privadas, a livre associação, a livre reunião, as liberdades de pensamento, expressão, autonomia da vontade, igualdade perante a lei, reparação dos danos sofridos, propriedade privada, além de uma série de direitos relativos às garantias do administrado perante os órgãos públicos e perante o ius puniendi estatal, as liberdades de comércio e indústria, etc. ${ }^{4}$

Já no campo dos direitos sociais (ou segunda geração), o art. 50 estabelece: "O Estado procurará o maior bem-estar de todos os habitantes do país, organizando e estimulando a produção e a mais adequada repartição da riqueza." A partir daí, as normas que seguem consagram uma série de direitos sociais, de caráter familiar, trabalhista, educativo e cultural.

Também é reconhecida uma série de direitos políticos, tendo como centro o sufrágio universal, secreto, direto e livre.

É importante destacar que não são expressamente reconhecidos direitos da chamada "terceira geração" geralmente caracterizados como os que dizem respeito aos interesses difusos. Mas o art. 48 tem um dispositivo que remete, para efeitos de complementar o parâmetro das liberdades públicas, aos tratados internacionais sobre direitos humanos devidamente ratificados pelo Legislativo, incluindo assim direitos de proteção ao meio ambiente, econômicos, etc.

\section{2- a distribuição do poder}

O art. $1^{\circ}$ da Constituição Política de 1949 estabelece que: "Costa Rica é uma República democrática, livre e independente." Com este postulado, os constituintes quiseram destacar principalmente o aspecto da proteção à vontade popular expressa mediante o sufrágio, tentando prevenir o retorno às fraudes eleitorais, como as que levaram à guerra de 1948.

Para desenvolver tal princípio democrático, foi estabelecida a separação dos poderes públicos, destacando-se a instauração de um órgão eleitoral com independência e autonomia similares aos do Judiciário. ${ }^{5}$ Estabeleceram-se

\section{Arts. 20 a 49.}

5. Art. 9: "O Governo da República é popular, representativo, alternativo e responsável. $E ́$ exercido por três poderes diferentes e independentes entre si: Legislativo, Executivo e Judiciário. Nenhum dos poderes pode delegar o exercício de funções que lhe sejam próprias. Um Tribunal 
também órgãos de controle público, em matéria fiscal, administrativa e constitucional. A este último dedicaremos a segunda parte do presente trabalho.

Reconheceu-se também o princípio de legalidade e a responsabilidade administrativa. O Exército foi dissolvido como instituição permanente. A ordem pública foi deixada à polícia civil. Esta foi dividida de acordo com sua função e competência territorial: preventiva urbana na "Guarda Civil", preventiva rural na "Guarda Rural" e repressiva urbana e rural no "Organismo de Investigação Judiciária". As duas primeiras dependem de diferentes Ministérios do Poder Executivo e a terceira está vinculada ao Poder Judiciário, junto com o Ministério Público. $^{6}$

O Poder Executivo fica com uma série de poderes públicos, destacando-se a possibilidade de nomear e remover os ministros do governo, de participar na formação das leis com a sanção ou o veto aos projetos de lei aprovados pela Câmara dos Deputados, a concessão do indulto, etc. Em contrapartida, o Legislativo fica com exclusividade quanto à aprovação dos orçamentos ordinário e extraordinário do Estado, aos atos com relevância de lei, bem como de autorizar ou não as saídas do país do presidente da República, etc. ${ }^{7}$

É outorgada autonomia administrativa, financeira e de gestão às autarquias, dentre as quais as universidades públicas, os municípios, as empresas públicas, etc. ${ }^{8}$

Concede-se aos tratados internacionais eficácia superior à das leis, sempre que devidamente ratificados pelo Congresso, mediante procedimento especialmente agravado ${ }^{9}$

Supremo de Eleições, com o caráter e independência dos poderes do Estado, tem a seu cargo em forma exclusiva e independente a organização, direção e vigilância dos atos relativos ao sufrágio, assim como as outras funções que lhe sejam atrubuidas por esta Constituição e as leis."

6. V. art. 12.

7. V. arts. 105 a 151.

8. V. arts. 84 a 88,168 a 175,188 a 190.

9. O art. 7 da Constituição de 1949 é empregado para justificar a inclusão dos tratados internacionais devidamente ratificados pelo Legislativo dentro do parâmetro de constitucionalidade. 
B a estrutura do Poder Judiciário

Seguindo o esquema da separação dos poderes públicos, a Constituição de 1949 estabelece a independência recíproca entre os diversos poderes da República. Reconhece apenas certos controles e cooperações inter-orgânicos, que permitem o funcionamento do sistema. Neste contexto, o Poder Judiciário tem o monopólio na função jurisdicional, desfrutando para isso de autonomia funcional e orçamentária, tendo o dever de ser imparcial em todas as suas atuações.

$\mathrm{O}$ art. 154 expressamente manifesta que: "O Poder Judiciário somente está submetido à Constituição e à lei, e as resoluções que efetue nos assuntos de sua competência $^{10}$ não lhe impõem outras responsabilidades que as expressamente estabelecidas pelas leis."

1 - órgãos que compõem o Judiciário

Pertence à estrutura do Poder Judiciário uma série de órgãos encarregados de funções propriamente jurisdicionais ou de apoio técnico ou logístico às atividades de julgamento das causas submetidas a seu conhecimento.

Nesse sentido, a pirâmide da hierarquia judiciária tem sua cúspide num órgão colegiado: a Corte Suprema de Justiça, formado por vinte e dois magistrados de carreira, tema que será aprofundado no ponto dois seguinte.

Seguindo a direção inferior do organograma do Judiciário costarriquense, encontram-se o Tribunal de Cassação Penal, os Tribunais Superiores (cada um deles composto por três juízes superiores), os Tribunais de Instrução, de Execução das Penas ou de Primeira Instância e as Alcaldías, encarregadas de conhecer dos assuntos de menor relevância social ou pecuniária.

Também fazem parte do Judiciário certos órgãos dependentes apenas da Corte Suprema, entre eles o Ministério Público, ${ }^{11}$ o Organismo de Investigação Judiciária, e outros órgãos de apoio, tais como o Arquivo Judiciário, o Digesto de Jurisprudência, a Revista dos Tribunais, etc.

10. Quando fala em "assuntos de sua competência", o constituinte fez expressa referência à matéria jurisdicional, ou seja, somente aquela que tem como finalidade imediata a resolução de um conflito social através do pronunciamento com caráter de coisa julgada.

11. O Ministério Público, embora ubicado dentro da estrutura administrativa do Poder Judiciário, conta com independência para o desempenho de sua função e o dever de imparcialidade, próprio da junção jurisdicional, da qual é apenas um colaborador. 


\section{2- a Corte Suprema de Justiça}

A Corte Suprema de Justiça, órgão de maior hierarquia dentro do Poder Judiciário, tem uma tripla função; ou pelo menos a têm seus membros. É composta por vinte e dois magistrados que, reunidos em plenário, decidem assuntos de caráter administrativo interno do órgão e questões propriamente jurisdicionais, como, por exemplo, o julgamento de autoridades que desfrutem do privilégio constitucional da imunidade e que estejam sendo questionadas em matéria criminal, depois de terem renunciado à sua imunidade ou de esta ter sido suspensa pelo órgão competente. Esta última função foi posteriormente declarada inconstitucional, por contradizer a norma constitucional que proíbe os privilégios no julgamento das diversas causas, por considerar que qualquer autoridade deveria, caso fosse cassada sua imunidade, ser julgada pelos tribunais ordinários destinados pela lei a tal finalidade.

A terceira função da Corte Suprema consiste no desempenho de cada magistrado em sua respectiva câmara. As câmaras são chamadas "salas" especializadas por competência em razão de matéria. Assim, a Corte encontra-se fragmentada em quatro salas especializadas: a Primeira, a Segunda e a Terceira, que conhecem de assuntos cíveis, trabalhistas e criminais, respectivamente. Cada uma é composta por um total de cinco magistrados. A Sala Constitucional, composta por sete juízes, é popularmente conhecida como "Sala Quarta". criada em 1989, para conhecer das questões de constitucionalidade em sentido bastante amplo, como se poderá ver e seguir.

Cabe reiterar que cada Sala tem sua composição e competências claramente delimitadas, ou seja, quem pertence à Sala Primeira atuará sempre e unicamente nessa Sala, sem ter competência para julgamento de outros assuntos. Somente atuará fora de sua matéria quando agir como membro da Corte Suprema, ou seja, em questões não propriamente jurisdicionais. Interessa-nos, em especial, destacar o papel da Sala Constitucional, motivo principal do presente trabalho.

Para ser magistrado da Corte Suprema, requer-se ser costarriquense por nascimento ou por naturalização com mais de dez anos de residência no país, ser cidadão em exercício de seus direitos, pertencer ao estado secular, ter exercido a profissão durante pelo menos dez anos, haver desempenhado outros cargos jurisdicionais e ser maior de trinta e cinco anos de idade. 
Parte II: O Tribunal Constitucional Costarriquense

O julgamento sobre matérias de relevância constitucional não é novo na história da Costa Rica, que já ensaiou com quase nenhum sucesso outras formas de justiça constitucional, antes de ser criada, mediante Lei n. 7.135, de 11 de outubro de 1989, a Sala Constitucional da Corte Suprema de Justiça.

A história anterior à criação da Sala Constitucional pode ser resumida em três períodos: 1812 a 1888 , de 1888 até 1938, e o tempo compreendido entre este ano e o de $1989 .{ }^{12}$ Esse resumo é apenas ilustrativo, já que não são bem exatos esses períodos.

O primeiro período caracterizou-se pela existência de um controle de tipo político da constitucionalidade, exercido por órgãos como o Congresso Nacional ou o Senado, mediante institutos como o veto. Não é necessário explicar as razões que levaram ao fracasso de tal sistema, pois, embora respeite ao extremo o esquema tradicional da separação dos poderes, o controle político da constitucionalidade das leis implica um certo grau de cultura jurídica e tradição democrática, que nem sempre existe nos países latino-americanos.

Num segundo espaço de tempo, a partir de 1888, e tendo como base o texto da Lei Orgânica dos Tribunais, adotou-se um sistema de tipo difuso, como o estabelecido nos Estados Unidos, no qual todos os órgãos encarregados de ministrar justiça deviam analisar e, no caso, não aplicar normas que considerassem contrárias ao texto da Constituição Política. O sistema quase não foi implementado. Quando o foi, verificou-se o problema das diferentes interpretações da Carta Fundamental, até que em 1938 foi concedido à Corte Suprema de Justiça, mediante emenda ao Código de Procedimentos Cíveis, o monopólio do controle da constitucionalidade das leis, deixando-se a proteção das liberdades públicas ao sistema difuso.

A adoção do sistema concentrado foi efetivada até o ano de 1949 , quando a nova Constituição reconheceu expressamente o papel da Corte como intérprete e defensora da Lei Fundamental. Embora representasse um avanço significativo com relação aos sistemas anteriores, a verdade é que o controle por parte da Corte Suprema nunca conseguiu alcançar seus objetivos. Isso somente se obteve após a criação da Sala Constitucional.

12. Saenz Carbonel, Jorge Francisco, "Orígenes del control de Constitucionalidad de las Leyes en Costa Rica", in Revista de Derecho Constitucional, n. 1, janeiro-abril de 1991, San José. Corte Suprema de Justicia, pp. 29 e ss. 
A - princípios inspiradores de sua função

$\mathrm{O}$ art. $1^{\circ}$ da Lei da Jurisdição Constitucional estabelece que tal lei "tem como fim regular a jurisdição constitucional, cujo objetivo é garantir a supremacia das normas e princípios constitucionais e os do direito internacional ou comunitário vigentes na República, a uniforme interpretação e aplicação dos mesmos e os direitos e liberdades fundamentais consagrados na Constituição ou nos instrumentos internacionais de direitos humanos vigentes na Costa Rica"

Daí, assim como do texto da referida Lei n. 7.135, pode ser extraída uma série de princípios que informam a atuação da Sala Constitucional na defesa da supremacia do ordenamento da Carta Política da República.

O primeiro faz referência à amplitude do parâmetro de constitucionalidade. Este é formado não apenas pelo texto da Lei Fundamental, mas também pelas normas internacionais de direitos humanos e outras, ratificadas pelo Legislativo, mediante o procedimento respectivo, assim como pelos princípios constitucionais, como também é ampliado por disposição jurisprudencial para abranger a prática ou o costume constitucional. ${ }^{13}$

Também o âmbito de aplicação é muito amplo, não sendo passíveis de impugnação apenas as normas que contrariam a Constituição, mas também os atos de aplicação das mesmas, sua interpretação e os efeitos que possam produzir. ${ }^{14}$

$\mathrm{O}$ segundo grande princípio da justiça constitucional costarriquense consiste em considerar a defesa da Constituição Política como assunto de interesse público. Assim, a atuação da Sala requer apenas provocação alheia. Mas, depois de instaurado um processo de constitucionalidade, sua atuação passa a ser realizada $e x$ officio.

A gratuidade e a informalidade são parte do terceiro princípio. $\mathrm{O}$ amparo e o habeas corpus precisam apenas de um meio escrito qualquer para serem interpostos, desfrutando-se para isso até de franquia postal. ${ }^{15}$

Também a celeridade é destacada como fundamento da justiça constitucional, especialmente no tocante à proteção dos direitos fundamentais. Nesse sentido, os prazos em matéria de amparo e habeas corpus são reduzidos e sua

13. V. art. 3 da Lei da Jurisdição Constitucional.

14. V. arts. 15,29 e 73 ibid.

15. V. arts. 18 e 38 ibid. 
tramitação é privilegiada em relação às de quaisquer outros processos. É dever da Sala manter sempre um magistrado de plantão e os meios necessários para que, vinte e quatro horas ao dia, possa atender às demandas dos particulares no menor prazo de tempo possível. Por razões de segurança, concede-se um prazo de prescrição para a interposição das demandas respectivas. ${ }^{16}$

As resoluções da Sala têm eficácia tanto para o passado quanto para o futuro, ficando a salvo apenas os direitos adquiridos de boa-fé. Este princípio é especialmente significativo no controle de constitucionalidade, que, em caso de sentença que declare a inconstitucionalidade, produz a anulação do ato questionado e seu consequiente desaparecimento do ordenamento vigente.

A jurisprudência e os precedentes da Sala têm efeitos erga omnes, exceto para si própria, o que na prática permite uma dupla vantagem: por um lado, uniformiza a interpretação do ordenamento constitucional e é um fator de certeza jurídica. Por outro, permite que, caso se efetue uma mudança na composição da Sala, a jurisprudência possa mudar e se adaptar às novas circunstâncias e necessidades. ${ }^{17}$

Também tem a Sala capacidade discricionária ampla, podendo retificar, adicionar ou suprimir parte de suas decisões, quando de outra forma se atentasse contra os interesses públicos, de modo mais prejudicial que mediante a violação alegada. Ou seja, a Sala não se encontra obrigada a decidir contra o interesse público, ou a segurança nacional, por exemplo, para a simples satisfação de interesses particulares.

B competências em matéria constitucional

A Sala exerce sua jurisdição mediante três tipos de atuações: a defesa dos direitos fundamentais, chamada também de jurisdição da liberdade, no controle da constitucionalidade dos atos públicos, e noutras funções, o que detalharemos a seguir.

16. V. arts. 19, 23, 35, 43 e 44 da Lei da Jurisdição Constitucional.

17. V. arts. 13,49 ibid. 
1 - jurisdição da liberdade ${ }^{18}$

Para a defesa dos direitos constitucionais, a Sala tem competência para conhecer dois tipos de processo: os recursos de amparo e de habeas corpus. Ambos se caraterizam por serem destinados a proteger os direitos consagrados na Constituição Política ou em tratados internacionais de direitos humanos, devidamente ratificados pelo país.

Eles têm em comum: o fato de serem considerados de prioritária e urgente tramitação, interpondo quaisquer outros assuntos que a Sala tivesse por decidir; bem como a existência de uma legitimação universal para iniciá-los (ou seja, qualquer pessoa pode interpor recurso de amparo ou habeas corpus, ainda que em benefício de um terceiro). Por fim, pela informalidade que os caracteriza, requer-se apenas de indicação do ato considerado lesivo e a autoridade responsável ou, ao menos, o órgão encarregado de aplicá-la.

\section{a. recurso de habeas corpus}

O habeas corpus é simultaneamente um direito subjetivo dos indivíduos e um processo constitucional. ${ }^{19} \mathrm{O}$ aspecto substantivo é consagrado pelo art. 48 da Constituição e o aspecto processual estabelecido pelos arts. 15 e seguintes da Lei da Jurisdição Constitucional.

Com este tipo de recurso, tenta-se proteger a liberdade e a integridade pessoais, a liberdade de locomoção, contra atos realizados por autoridades públicas que indevidamente, ou seja, ilegitimamente, interrompam ou ponham em perigo tais direitos ou seu efetivo desfrute.

Existem quatro tipos de habeas corpus: o reparador, como no caso das detenções ilegais. Neste caso, o recurso tem a finalidade de fazer com que a pessoa recupere o uso de sua liberdade arbitrariamente perturbada. $\mathrm{O}$ preventivo, dado aos cidadãos para proteger-se contra a ameaça de eventuais detenções; aqui, o objetivo é obter uma sentença que restrinja a eventual atuação da autoridade, ou deixe sem efeito uma resolução ilegal que representara a ameaça da liberdade. No tipo restritivo, chamado assim porque sua finalidade é a de fazer cessar perturbações

18. O termo é empregado por Hernandes Valle, Rubén, Derecho Procesal Constitucional, San José, Editorial Juricentro S.A., 1994, p. 38, entendida em sentido restrito como: '...constituída por uma série de instrumentos processuais dirigidos à tutela dos direitos fundamentais."

19. Hernandez Valle, Rubén, El Derecho de la Constitución, Editorial Juricentro S.A, San José, 1993. 
e restrições à liberdade pessoal; o objetivo é que a Sala emita uma ordem de prevenção contra a autoridade, sendo similar à instituição anglo-saxônica do warrant. E o habeas corpus corretivo, dado com o objeto de fazer mudar o local onde esteja o detento, caso não seja o adequado para a qualificação legal deste. ${ }^{20}$

Recebido um recurso deste tipo na Sala, ele é imediatamente transferido para um dos magistrados, chamado de "instrutor", que estudará a possibilidade de dar tramitação ao recurso, em cujo caso será emitida ordem à autoridade coatora, para que, no prazo máximo de três dias, restitua ao recorrente o desfrute de seus direitos ou apresente provas da legitimidade de seus atos. A apresentação de tal relatório é obrigatório e sua desatenção, assim como a inexatidão ou falsidade dele sujeitará o infrator às penas previstas pela lei. No caso, de prisão e interdição profissional.

Caso o recurso seja resolvido em favor do recorrente, a Sala ordenará que a este seja restabelecida a liberdade perturbada e condenará em abstrato o órgão ao pagamento dos danos e prejuízos causados, que será liquidado em processo de execução de sentença perante a jurisdição contenciosa administrativa.

b. o recurso de amparo

O modelo costarriquense, inspirado inicialmente na legislação cubana dos anos quarenta, apresenta características próprias, porquanto se trata de um amparo inicial e não de um final, como é na maioria das legislações. Portanto, o amparo costarriquense procede contra atuações administrativas do Estado, mas é incabível contra decisões judiciais. $^{21}$

Diz o art. 29 da Lei da Jurisdição Constitucional que: "o recurso de amparo garante os direitos e liberdades fundamentais a que se refere esta lei, salvo os protegidos pelo de habeas corpus" Procede o recurso contra "toda disposição, acordo ou resolução e, em geral, contra toda ação, omissão ou simples atuação material não fundada em ato administrativo eficaz, dos servidores e órgãos públicos, que tenha violado, viole, ou ameace violar quaisquer daqueles direitos... $O$ amparo caberá não-só contra os atos arbitrários, mas também contra as

20. Hernandez Valle, ob. cit., pp. 676 a 679.

21. Hemandez Valle, ob. cit., p. 686. 
atuações ou omissões fundadas em normas erroneamente interpretadas ou indevidamente aplicadas." 22

São reconhecidas duas modalidades de amparo: o primeiro pode ser interposto contra autoridades públicas; o segundo contra sujeitos de direito privado que atuem ou devam atuar em exercício de funções ou poderes públicos, ou estejam, de fato ou de direito, numa posição de poder perante a qual os remédios jurisdicionais comuns resultem tardios ou insuficientes para garantir os direitos ou liberdades fundamentais tutelados pelo amparo contra servidores públicos. ${ }^{23}$

A tramitação e conseqüências dadas a este tipo de recurso são similares aos do habeas corpus, apenas reiterando que o primeiro sempre tramitará com prevalência sobre qualquer outro, inclusive sobre o amparo. ${ }^{24}$

Encontram-se fora do alcance do amparo as leis e outras fontes normativas, as resoluções do Poder Judiciário, os atos administrativos que executem tais resoluções, os atos que carreguem conseqüências meramente patrimoniais nos quais o administrado tenha dado validamente seu consentimento e os atos e disposições do Tribunal Supremo Eleitoral em matéria de sua competência exclusiva de interpretar a Constituição em questão eleitoral.

2- controle de constitucionalidade

Controle de constitucionalidade é a verificação de um ato lesivo (particularmente da lei) à Constituição. ${ }^{25}$ A Constituição Política, em seu art. 10, amplia o âmbito de aplicação do controle aos outros atos com caráter normativo (regulamentos administrativos) e aos outros atos sujeitos ao direito público.

A Lei da Jurisdição Constitucional estabelece dois mecanismos principais de controle da constitucionalidade: as consultas judiciárias e legislativas e a ação de inconstitucionalidade, a cada uma das quais nos referiremos a seguir.

Em todo caso, resulta importante salientar um aspecto que já foi mencionado: o parâmetro de constitucionalidade estabelecido pela lei compreende

22. Ver art. 29 da Lei da Jurisdição Constitucional.

23. Os arts. 29 a 56 falam do amparo contra autoridades públicas, no entanto os arts. 57 a 65 disciplinam o amparo contra sujeitos do direito privado.

24. V. art. 30 da citada Lei.

25. Ferreira Filho, Manoel Gonçalves, Curso de Direito Constitucional, $22^{2}$ ed., São Paulo, Saraiva, 1995, p. 30. 
não apenas as normas positivas, mas inclui os princípios constitucionais, o costume constitucional, o Regulamento Interno da Assembléia Legislativa, os tratados internacionais ratificados, seguindo as regras do art. 7 e a Constituição derrogada de 1871 para os atos promulgados na época e que não forem contrários à atual Carta.

Sendo um controle realizado por um só órgão, pode-se dizer que é um controle concentrado. Pela natureza do órgão que decide sobre a constitucionalidade, é um controle judiciário. Pode tanto ser controle prévio, quanto posterior, tanto incidental, quanto principal, como veremos a seguir.

a. as consultas de constitucionalidade

Existem dois tipos de consultas: a legislativa e a judiciária.

A consulta legislativa de constitucionalidade é um encaminhamento de um projeto antes da consolidação de um procedimento legislativo, para que a Sala resolva se há ou-não incompatibilidades com a Lei Fundamental. A consulta pode ser preceptiva ou obrigatória, quando esteja sendo emendada a Constituição, ou sendo aprovado um tratado internacional, ou sendo feitas reservas ao mesmo. Também pode ser encaminhada a consulta sobre um projeto qualquer, apresentada por petição de pelo menos dez deputados; por provocação da Corte Suprema de Justiça, do Tribunal Supremo de Eleições ou do Tribunal de Contas da República, bem como do Defensor dos Habitantes (este último, quando o projeto envolver violação de direitos fundamentais). Nos casos de consulta não-obrigatória, a mesma deverá fundamentar as razões que levam à suspeita da existência de um vício de inconstitucionalidade no projeto.

Nestes casos, a decisão emitida pela Sala terá efeito vinculante somente quando estabelecer a existência de trâmites inconstitucionais no projeto consultado.

A consulta judiciária poderá ser levantada por qualquer juiz, que emitirá resolução a respeito e remeterá os autos pertinentes à Sala, para que esta resolva sobre a questão de constitucionalidade.

b. a ação de inconstitucionalidade

A ação de inconstitucionalidade é um processo de revisão da constitucionalidade dos atos públicos solicitado por um indivíduo, seja um particular, ou seja uma das autoridades expressamente autorizadas para tal função. Baseia-se na supremacia que têm as normas e princípios constitucionais sobre as 
outras normas que componham o ordenamento de uma determinada sociedade, e do princípio de regularidade jurídica, segundo o qual os atos normativos devem sujeitar-se aos que sejam hierarquicamente superiores a eles. Assim, o controle visa decidir se existe ou-não violação a estes princípios, e resolver em favor ou contra a validade a norma infraconstitucional analisada.

Pode ser pleiteada contra leis ou outros atos normativos, contra os atos subjetivos das autoridades públicas, contra as emendas constitucionais que violarem as normas de procedimento, contra o ato de ratificação de tratados internacionais ou contra estes, ou contra a inércia, as omissões e as abstenções das autoridades públicas. $^{26}$

Têm legitimação para acionar na via constitucional quem tenha um processo pendente de decisão perante os tribunais. Não será necessário haver processo em andamento quando, pela natureza do assunto, não exista lesão individual e direta, ou se pretenda a defesa de interesses difusos, ou que atingem toda a coletividade. Também estão legitimados para acionar perante esta via o Presidente do Tribunal de Contas, o Procurador Geral da República e o Defensor dos Habitantes (Ombudsman) ${ }^{27}$

Como resulta fácil apreciar, a Lei da Jurisdição Constitucional misturou uma série de formas de controle presentes na doutrina e na legislação comparadas. A consulta legislativa é um claro exemplo de controle preventivo, enquanto a ação e a consulta judiciária o são de controle posterior ou repressivo. Também, a legitimação para acionar a inconstitucionalidade de um ato pode ser do tipo incidental (ter um caso pendente) ou principal (nos outros casos).

Os efeitos em geral do funcionamento do controle de constitucionalidade têm sempre um traço comum: um ato declarado inconstitucional é um ato anulado, eliminado do ordenamento jurídico, sendo que apenas os direitos adquiridos de boa-fé podem subsistir.

3- outras competências

A Lei n. 7.135 ainda estabelece mais uma competência para a Sala Constitucional. Trata-se da função de resolver os conflitos de competência surgidos entre os poderes do Estado, incluído o Tribunal Supremo de Eleições, ou entre eles e

26.Ver art. 73 da Lei da Jurisdição Constitucional.

27.Ver art. 75 da citada Lei. 
o Tribunal de Contas. Também resolve os conflitos de competências constitucionais entre quaisquer dos poderes e as entidades descentralizadas, municipalidades ou outras pessoas de direito público, ou aqueles surgidos entre esses entes e outros da Administração indireta. ${ }^{28}$

\section{Conclusão}

Em todo caso, a resposta que as autoridades tiveram com relação à justiça constitucional demonstra que seu desempenho tem sido positivo. Pela primeira vez na história do país, a Constituição Política aproximou-se da tãodesejável normatividade com que Loewenstein qualificou às cartas dos países politicamente mais desenvolvidos.

A revolução institucional produzida na Costa Rica logo após a implementação da Sala Constitucional demonstrou dois aspectos de similar magnitude e relevância: por um lado, as violações à supremacia constitucional e aos direitos assim consagrados, que vinham sendo cometidas pelas autoridades eram largamente estimuladas por um sistema de controle inexistente ou estéril de constitucionalidade; por outro, a implementação da justiça constitucional nos termos citados provocou grandes críticas de parte dos membros de cúpula dos poderes Executivo e Legislativo, que observavam como a arbitrariedade de seu poder estava sendo consumida por uma onda de normatividade constitucional que contagiou a todos os extratos da sociedade costarriquense.

A existência de um órgão independente e especializado para tratar de um assunto tão-delicado, quanto à interpretação da Constituição, poderia servir eventualmente para que em outros países da instável região latino-americana, se afastasse cada vez mais do uso arbitrário e desmedido do poder político e suas adversas conseqüências. A normatividade constitucional pode nascer ou da vivência popular não-institucionalizada ou de mecanismos que obriguem as autoridades públicas a respeitar as normas que subjassem dos textos positivados na Constituição Política.

São Paulo, janeiro de 1996. 


\section{BIBLIOGRAFIA}

BOBBIO, Norberto. Liberalismo y Democracia. $2^{\mathrm{a}}$ ed. em espanhol. México : Fondo de Cultura Económica, 1992.

COSTA RICA, leis e decretos. Constitución Política de la República de Costa Rica. de 7 de novembro de 1949.

Ley de la Jurisdicción Constitucional, n. 7.135 de 11 de outubro de 1989.

Ley General de la Administración Pública, n. 6.227 de 1979.

Ley Reguladora de la Jurisdicción Contensioso-Administrativa, n. 3.667 de 12 de março de 1976.

CALDERÓN, Grover. Constitución Política y Derechos Humanos. $1^{\mathrm{a}}$ ed. Lima : Instituto de Derechos y Ciencias Políticas, 1994.

FERREIRA FILHO, Manoel Gonçalves. Curso de Direito Constitucional. $22^{\mathrm{a}}$ ed. São Paulo : Saraiva, 1994.

GUTIERREZ, Carlos José. El Funcionamiento del Sistema Jurídico. San José : Editorial Juricentro S.A, 1979.

HERNANDEZ VALLE, Rubén. Derecho Procesal Constitucional. $1^{\text {a }}$ ed. San José : Editorial Juricentro, 1994.

El Derecho de la Constitución. $1^{\mathrm{a}}$ ed. San José : Editorial Juricentro,1993. 2 vs.

KELSEN, Hans. Teoría General del Derecho y del Estado. México : Imprenta Universitaria, 1949.

SAENZ CARBONEL, Jorge. El Despertar Constitucional. $1^{\text {a }}$ ed. San José : Libro Libre, 1985.

Orígenes del control de constitucionalidad de las Leyes en Costa Rica in Revista de Derecho Constitucional, n. 1 Janeiro-abril de 1991. San José : Corte Suprema de Justicia. 